\title{
Social Spending, Welfare and Redistribution: A Comparative Analysis of 22 European Countries
}

\author{
Maria Alessandra Antonelli, Valeria De Bonis* \\ Sapienza University of Rome School of Law Department of Legal, Philosophical and Economic Studies Piazzale Aldo Moro, \\ Rome, Italy \\ Email: alessandra.antonelli@uniroma1.it, *valeria.debonis@uniroma1.it
}

How to cite this paper: Antonelli, M.A. and De Bonis, V. (2017) Social Spending, Welfare and Redistribution: A Comparative Analysis of 22 European Countries. Modern Economy, 8, 1291-1313. https://doi.org/10.4236/me.2017.811087

Received: October 12, 2017

Accepted: November 13, 2017

Published: November 16, 2017

Copyright $\odot 2017$ by authors and Scientific Research Publishing Inc. This work is licensed under the Creative Commons Attribution International License (CC BY 4.0).

http://creativecommons.org/licenses/by/4.0/

c) (i) Open Access

\begin{abstract}
This paper aims at analysing the effectiveness and the efficiency of social public expenditure in 22 European countries. We present a basic theoretical framework connecting the choice of the level of social protection to the median voter's preferences and the inefficiency of expenditure. To test it against real data, we construct performance and efficiency indicators. While the existing literature measures the performance of social policy restricting the analysis to its impact on inequality and the labour market, our index summarises the outcomes achieved in all sectors of social protection (family, health, labour market elderly, disabled, unemployment, inequality). Based on this, we find that the ranking of countries differs from those found in the literature. We then put together performance and the amount of expenditure needed to achieve it (to better compare countries, we use social public expenditure net of tax and transfers), constructing efficiency indicators. Our results suggest that countries with a higher social expenditure inefficiency index present a greater variability of performance in all subsectors considered.
\end{abstract}

\section{Keywords}

Median Voter Model, Social Performance Index, Social Expenditure Efficiency

\section{Introduction}

\subsection{Aims and Scope}

The effectiveness and efficiency of social public expenditure in European countries has been the object of political and theoretical debate along the convergence path undergone by national welfare systems [1]. This is taking place as an effect 
of common factors, like the economic crisis, an ageing population, and the working of European guidelines.

Within this debate, the aim of this paper is to study the outcomes and the efficiency of social policies in European countries as they appear in 2013, the last year for which it is possible to obtain data for a fairly large number of countries (22). We do this through two contributions to the existing literature.

First, we present a basic median voter model that connects the choice of social benefits level to the efficiency of social expenditure and to preferences for private goods and welfare services. Coherently with the risk protection function of welfare systems, we assume that the relative weight of publicly provided social protection services within the utility function increases as the individual moves down the income distribution.

Second, we construct an aggregate indicator for social protection performance, meaning for that the achievement degree of social policy goals. The performance index we present summarises the outcomes achieved in all sectors of social protection, as specified in the OECD Social Expenditure Database (SOCX): family, health, labour market, elderly, disabled, unemployment, and inequality.

\subsection{Literature Review}

The bulk of the existing literature on the performance and efficiency of the public sector considers either general government expenditure or expenditure for specific public services.

As for the former, Afonso et al. [2] provide an international comparison of the efficiency of the public sector; Afonso and Kazemi [3] analyse the efficiency of public spending in 20 OECD countries; Afonso et al. [4] concentrate on the new EU member states and on emerging markets; Tanzi [5] analyses the issue in the more general context of the role of government intervention, while Tanzi and Schuknecht [6] put it in the perspective of the globalisation process.

As for sectorial analyses, among others, Clements [7] looks at efficiency in education spending, Vanden Eeckhaut et al. [8] at local jurisdictions, Fakin and Crombrugghe [9] at social transfers in transition economies, and Gupta and Verhoeven [10] at the experience of Africa as for public spending on education and health.

Studies specifically addressing welfare states typically restrict the analysis of their impacts on three areas: economic growth, poverty and inequality, labour market rigidities. Among these, Boeri [11] and Sapir [12] only consider the EU-15 countries and do not use an aggregate performance index, thus providing sectorial effectiveness analyses (labour market, poverty, redistribution, old age). Caruana [13] compiles an aggregate outcome indicator using a Principal Component Analysis, considering five sectors (growth, poverty, inequality, labour market, unemployment).

The performance index we present in the paper, instead, summarises the outcomes achieved in all sectors of social protection, as specified in the OECD So- 
cial Expenditure Database (SOCX): family, health, labour market, elderly, disabled, unemployment, and inequality.

Differently from the above mentioned literature, we also try to provide a theoretical framework explaining the choice of social benefits based on the median voter preferences and the inefficiency of social expenditure.

In our model, welfare services enter the utility function irrespective of whether the individual directly receives welfare services or not. This feature intends to capture the risk reducing function of welfare systems, connected to the ability of the government to handle moral hazard problems better than private companies in providing income insurance [14]; the issue is tackled also in the public choice literature [15]. Different explanations are altruism, that is, concern for others, through the interdependence of the utility functions [16] or the intent of ensuring social cohesion [17].

Another feature of our model is that the amount of welfare services provided by the government can differ from the amount needed to finance them, because of inefficiencies in the transfer process. These can stem from the spending side, that is, some resources are wasted in the process of being distributed to beneficiaries when the production/provision is not realised at the minimum cost. For this aspect see, for example, the public choice literature, in particular the seminal work by Migué and Bélanger [18].

The existing literature also considers the connection between welfare expenditure and the distribution of income. In the political economy literature, as suggested by Downs [19] and Meltzer and Richard [20], majority voting can explain redistributive expenditure on the basis of the shape of the income distribution. Typically, the bulk of the distribution consists of many small incomes, with some very large incomes in its extended tail. Thus, the median voter income will be less than that of the mean voter, with majority voting leading to redistribution from the richer minority to the poorer majority, with the consequent effects on inequality [21] and growth [22]; Milanovic [23] and Barnes [24] provide recent theoretical extensions and empirical tests.

In our model, redistribution is not the driving force, since the median voter need not be among the net beneficiaries of the system. The position in the distribution of income, instead, is relevant for determining the intensity of preferences according to the insurance motive. This is in line with the risk protection function of the welfare system and with the suggestion that individuals become increasingly risk averse as they move closer to poverty [25] [26].

Finally, even if we consider a closed economy, the general structure of our model is similar to the open economy ones by Brueckner [27] and Razin and Sadka [28].

The paper proceeds as follows. Section 2 presents the theoretical framework; the performance index and the inefficiency index are derived and tested against the predictions of the models in Sections 3 and 4, respectively. Section 6 summarises the main results of the paper. 


\section{The Theoretical Framework}

We consider a basic median voter model. The economy is composed by $N$ individuals, who differ as for preferences and income endowments. The government provides social protection and finances it through taxation. The choice of the level of welfare services is the result of the maximisation of the median voter's utility function.

\subsection{The Government Functions}

The government provides welfare services. For simplicity, these are considered as a composite good of unitary cost and price. Each beneficiary receives an amount $g$, that can thus be interpreted either as a vector of services or as the implicit income deriving from it. In the first case, services can be either "categorical" cash transfers (for instance, old age, unemployed, disabled), or services having the characteristics of pure public goods (for instance, in the areas of health, inequality, labour market, family).

Let us call $\tilde{N}$ the number of beneficiaries and $\beta=\frac{\tilde{N}}{N}$ the corresponding share of population receiving welfare benefits. The number of people receiving welfare benefits and the amount of assistance paid are determined by eligibility and entitlement rules.

According to the definitions by Saunders [29], eligibility derives from the specification of the categories of the population qualifying for consideration for assistance; entitlement, instead, refers to the set of rules that determine the amount of benefits received by those who are eligible, according to some claimant's characteristics (for the effects on eligibility and entitlement rules in the health care sector see Swann) [30].

In our framework, the amount of benefits is the same for all recipients. Thus, we will call $\beta$ the eligibility parameter, defining the share of the population eligible for the provision of social assistance. The case of $\beta=1$ applies to a welfare system providing social services to all individuals, while $\beta<1$ corresponds to a welfare system targeting only some categories of the population, based on exogenously given eligibility criteria. Changes in the amount of social protection that each beneficiary is entitled to receive are, instead, represented by a change in the level of $g$. Total welfare services provided will thus amount to $g \beta N$.

This can differ from the amount needed to finance them, because of inefficiencies in the transfer process. These can stem from the spending side, that is, some resources are wasted in the process of being distributed to beneficiaries, and from the revenue side, that is, funds are collected by means of distortionary taxation. In what follows, we concentrate on inefficiency in expenditure.

Thus, total welfare expenditure is given by

$$
S=\alpha g \beta N, \quad \alpha \geq 1
$$

where $\alpha$ is the inefficiency parameter. The case of $\alpha=1$ corresponds to an 
efficient provision of welfare services, while $\alpha$ will exceed 1 in the presence of waste, a higher level of $\alpha$ corresponding to a larger waste.

Welfare benefits are financed by means of a fixed tax and the government budget constraint imposes that total revenues, $R$, equal total expenditure, $S$ :

$$
R=S
$$

As for the individual contribution, we distinguish two cases.

Case 1. All $N$ individuals pay the fixed tax. Then, given Equations (1) and (2), the welfare cost for each individual, $T$, is given by:

$$
T=\frac{R}{N}=\alpha \beta g
$$

Case 2. Those who are eligible for receiving welfare services do not contribute. Note that this case applies only if $\beta<1$; then, the individual contribution paid by the fraction $(1-\beta)$ of the population will be given by:

$$
T=\frac{R}{N-\tilde{N}}=\frac{\alpha \beta g}{1-\beta}
$$

\subsection{The Individual Utility Function}

We assume that individual utility depends on $g$ and on disposable income, that is, income net of the flat tax raised by the government to finance welfare expenditure. We assume that each individual $i$ maximises the following Cobb-Douglas utility function:

$$
U_{i}=g^{k_{i}}\left(Y_{i}-T\right)^{\left(1-k_{i}\right)}
$$

where $Y_{i}$ is individual $i$ s income, considered exogenous. For welfare recipients, $T$ would equal 0 in case 2 .

Note that $g$ enters the utility function irrespective of whether the individual directly receives welfare services or not. As mentioned in Section 1, this feature captures the risk reducing function of welfare systems.

Individuals differ as for $Y_{i}$ and $k_{i}$. In particular, we assume that $k_{i}$ depends on the relative position of the individual within income distribution, being positively correlated to the ratio $\frac{\overline{Y_{\min }}}{Y_{i}}$. Let us assume that:

$$
k_{i}=\frac{Y_{i}+\overline{Y_{\min }}}{2 Y_{i}}
$$

where $\overline{Y_{\min }}$ is the upper bound level of the first decile (i.e., the $10 \%$ of people with lowest incomes). Thus, the relative weight of $g$ within the utility function increases as the individual moves down the income distribution.

This is in line with the risk protection function of the welfare system mentioned above and with the suggestion that individuals become increasingly risk averse as they move closer to poverty, as argued in Section 1. 


\subsection{The Government Maximisation Problem}

The level of $g$ is decided by majority voting; thus, the government maximises the median voter's utility function w.r.t. $g$ only, subject to the budget constraint (Equation (2)):

$$
\max _{g} U_{m}=g^{k_{m}}\left(Y_{m}-T\right)^{\left(1-k_{m}\right)}
$$

s.t. Equation (2)

where $m$ denotes the median voter.

Since $k_{m}=\frac{Y_{m}+\overline{Y_{\min }}}{2 Y_{m}}$, its value increases as the median voter's income comes closer to $\overline{Y_{\min }}$.

The connection between welfare expenditure and the distribution of income that this implies is different from the one stemming from majority voting. In our model, redistribution is not the driving force, since the median voter need not be among the net beneficiaries of the system (this feature can, however, be captured in case 2, if the median voter belongs to the targeted categories and therefore benefits from welfare expenditure without contributing to it). The position in the distribution of income, instead, is relevant for determining the intensity of preferences according to the insurance motive.

\section{The Optimal Solution}

We consider two cases of the maximisation problem.

\section{Case 1}

In case 1, $T$ is given by Equation (3); by using it and substituting from the budget constraint (2) into (5), one obtains the following objective function, $W$ :

$$
W=g^{k_{m}}\left(Y_{m}-\alpha \beta g\right)^{\left(1-k_{m}\right)}
$$

By applying a log-linear transformation, Equation (6) becomes:

$$
k_{m} \log (g)+\left(1-k_{m}\right) \log \left(Y_{m}-\alpha \beta g\right)
$$

The F.O.C. is:

$$
\frac{\mathrm{d} W}{\mathrm{~d} g}=\frac{k_{m}}{g}+\frac{1-k_{m}}{Y_{m}-\alpha \beta g}(-\alpha \beta)=0
$$

that yields:

$$
g^{*}=\frac{k_{m} Y_{m}}{\alpha \beta}
$$

Note that the F.O.C. is sufficient for a maximum, given the usual assumptions on the concavity of the utility function and the linearity of the constraint.

Case 2

In case 2, $T$ is given by Equation (3'); by using it and substituting from the budget constraint (2) into (5), the objective function becomes:

$$
W=g^{k_{m}}\left(Y_{m}-\frac{\alpha \beta g}{1-\beta}\right)^{\left(1-k_{m}\right)}
$$


By taking logs as above, the F.O.C. yields:

$$
g^{*}=\frac{k_{m}(1-\beta) Y_{m}}{\alpha \beta}
$$

Based on these results, one can state the following claims.

Claim 1. The equilibrium amount of welfare services to which each beneficiary is entitled increases as the ratio between the upper bound income level of the first decile and the median voter's income increases.

Proof. The proof is straightforward by inspection of Equations (8) and (8'), recalling that $k_{m}=\frac{Y_{m}+\overline{Y_{\min }}}{2 Y_{m}}$, which increases with $\frac{\overline{Y_{\min }}}{Y_{m}}$. Intuitively, the claim points out that social preferences are more oriented towards social protection services in societies with higher concentration in the lower tail of income distribution. On the contrary, social preferences are more oriented towards private goods in societies with a greater concentration in the upper tail.

Claim 2. The equilibrium level of $g$ increases in the median voter's income, $Y_{m}$.

Proof. Let $k_{m} Y_{m}=z$. So, we have $z=\frac{Y_{m}+\overline{Y_{\min }}}{2 Y_{m}} \cdot Y_{m}$. Thus, $\frac{\partial g}{\partial Y_{m}}=\frac{1}{2 \alpha \beta}$. The same obtains by differentiating Equation (8'). An increase in $Y_{m}$ has a composite effect on the amount of social protection $g^{*}$. As the median income increases, $k_{m}$ decreases, with a negative effect on $g^{\star}$ (claim 1 ); however, there is also a positive direct effect, which prevails, thus generating a net increase of $g^{\star}$. Conceptually, this means that social protection is a normal good and the demand for it increases with income.

Claim 3. The equilibrium level of $g$ is inversely related to the inefficiency parameter $\alpha$ and to the eligibility parameter $\beta$.

Proof. The proof is straightforward by inspection of Equations (8) and (8').

Proposition 1. The values of the inefficiency parameter $\alpha$ and of the eligibility parameter $\beta$ are inversely related at the optimum; the elasticity of $\beta$ w.r.t. $\alpha$ is, in absolute value, equal to 1 in case 1 and smaller than 1 in case 2 .

Proof. The proof of the first part of the proposition is straightforward by inspection of Equation (8) and Equation (8'), respectively. As for the second part, in case 1, taking the total differential of Equation (8), one obtains $-\frac{\mathrm{d} \beta}{\mathrm{d} \alpha} \frac{\alpha}{\beta}=1$; this means that $\alpha$ and $\beta$ are perfect substitutes, since a greater inefficiency can be compensated by an equal reduction in $\beta$. In case 2 , taking the total differential of Equation (8'), one obtains $-\frac{\mathrm{d} \beta}{\mathrm{d} \alpha} \frac{\alpha}{\beta}=1-\beta$. This is because a percentage change in the share of beneficiaries corresponds to an opposite one in the share of tax-payers; thus, an increase in $\alpha$ is compensated by a decrease in $\beta$ that is smaller than in case 1 .

Claim (3) and proposition (1) present a simple illustration of how a reduction in social security expenditure can be achieved in either of the following ways: a) 
by improving efficiency (reduction of $\alpha$ ); b) by restricting eligibility (reduction of $\beta$ ); c) by reducing the level of individual protection (reduction in $g$ ), which, if the amount of assistance received could vary across recipients, e.g. based on their income level, would correspond to a tightening in the entitlement rules.

Nowadays, in the face of budgetary pressures, governments are resorting to income and/or means testing to guarantee social support to the least well-off [31], following ways b) and c). Individual means test is referred to as selectivity; in its broader sense, the term also encompasses the narrowing of the scope of eligible categories. An alternative concept is that of targeting, implying the redirection of expenditure to those whose needs are greatest or whose means are lowest [29].

These measures are commonly associated to an improved efficacy of policies, also hinting at an improved efficiency in the use of resources. This conclusion should, however, be taken with cautiousness: first, selectivity and targeting are not always successful [32]; second, they can possibly be used as a substitute for waste reduction, if governments are unwilling or unable to improve efficiency (proposition 1).

\section{Testing the Model against Empirical Evidence: Outcome Indicators for Social Policy}

In this section, we want to test the previous model against empirical evidences. To this purpose, we use OECD and Eurostat data to calculate, first, a social protection performance index (SPPI) representing the outcomes produced by welfare policies in 22 European countries in the year 2013. We use the most recent available data where the 2013 data are missing. In general, social policy is a multidimensional policy when considering several sectors of action. In addition to categorical measures, providing benefits to selected categories of beneficiaries only (e.g., for old age, the disabled, the unemployed), there are more general policies with non-excludable benefits (labour market, health, income inequality, family).

In this perspective, following Antonelli and De Bonis [33], we first identify eight sectors indicators for seven areas of social protection expenditure: family, health, labour market, elderly, disabled, unemployment, inequality. The expenditures sectors are those included in the SOCX database. We use eight indicators because we consider poverty as an additional indicator for social policies (see Appendix). Then, we select outcomes indicators for each sector. These outcomes can also be interpreted as the achievement's degree of the targets set out by policy-makers for different social areas. As a second step, we construct a composite index, summarising all outcomes indicators and, therefore, representing the social benefit provided-on average-to citizens (the $\beta g$ in the theoretical framework).

For each sector, we consider the following outcomes indicators correlated to the overall goal of the social policy in that sector (see the Appendix for details): 
$\checkmark$ maternal employment and net disposable family income for the family sector, since the related policies are mainly oriented towards reconciling work and family life-thus encouraging a greater women's participation in the labour market-and providing tax benefits (deductions and tax credits) or monetary transfers to families with children, to support their income level and, ultimately, in order not to discourage births; the data for maternal employment are available from OECD; net disposable income is calculated by subtracting the income tax (considering deductions or tax credits) and social contributions from gross taxable income (adjusted for deductions) and adding monetary benefits.

$\checkmark$ life-expectancy at birth for the health sector; these data are directly available from OECD;

$\checkmark$ the unemployment rate (in the three types of general, female and youth unemployment rate) to assess the performance of active labour market policies, that is, all those initiatives (such as training, work-related education, apprenticeships, careers guidance tools, etc.) designed to promote employment and work placement; these data are directly available from OECD;

$\checkmark$ the net replacement rate, i.e. the proportion of labour income (net of fiscal measures) which the national welfare systems respectively guarantee to the elderly and the unemployed after their exit from the labour market; for the elderly, we have used the net replacement rate relating to compulsory pension schemes, which represents the percentage of individual income, net of contributions and taxes, that the pension system guarantees after exiting the job market; for the unemployed, we consider the proportion of net labour income replaced by net benefits during the first year of unemployment;

$\checkmark$ the monetary benefits that, on average, national governments provide to the disabled (in the form of disability pensions or monetary transfers, to pay medical expenses and for care and assistance); in particular, we consider the monetary amount net of taxes-the corresponding data are directly available from Eurostat;

$\checkmark$ the Gini index calculated based on after-tax and transfers disposable income for income inequality; these data are directly available from OECD;

$\checkmark$ the poverty index (calculated as the percentage of households with disposable incomes at least 60 percent lower than the median national income) is considered as an indicator of the effectiveness of social policies aimed at ensuring a given standard of living; the source of data is the OECD "Income distribution and poverty" database, that refers to the "equivalised disposable household income", that is, household income net of taxes and inclusive of transfers received adjusted for household composition based on equivalence scales.

\subsection{Calculating the Social Protection Performance Index (SPPI)}

Our performance index for the $I^{\text {th }}$ country and $f^{\text {th }}$ sector of social policy at time $t$ is thus given by: 


$$
\begin{gathered}
0 \leq P_{i, j, t}=\frac{x_{i, j, t}-x_{\min , j, t}}{x_{\max , j, t}-x_{\min , j, t}} \leq 1 \\
i=1,2, \cdots, 22 ; j=1,2, \cdots, 8
\end{gathered}
$$

where $x_{i, j, t}$ is the value of the outcome indicator associated to the sector $j$ of social policy in country $i$ at time $t$, while $x_{\min , j, t}$ and $x_{\max , j, t}$ represent, respectively, the minimum and maximum values for the same indicator within the group of the 22 countries under consideration. Therefore, the performance index ranges between 0 and 1. $P_{i, j, t}=0$ indicates the case in which the $i^{\text {th }}$ country exhibits the worst performance in the $f^{\text {th }}$ sector at time $t$ within the group of countries under consideration; conversely, $P_{i, j, t}=1$ represents the best outcome in the $f^{\text {th }}$ sector at time $t$ for the $I^{\text {th }}$ country. To ensure that the highest values of the index are representative of the best performances, we transform three variables: the unemployment rate, the poverty index and the Gini index. In these cases, higher values of the index would indicate worse-and not better-performances for the country concerned. We therefore consider the complement to one of the preceding three outcome variables interpretable as the employment rate, a "welfare index" (representative of the percentage of households with disposable income of over 60 percent of the median disposable income) and an index of equidistribution of disposable income, respectively.

For the sectors with several outcomes' indicators (for example family, labour market, elderly, unemployment, etc.), we consider their average value, following the methodology used in calculating the Human Development Indices (see the Appendix for details; methodological notes available at the following link. http://hdr.undp.org/en/content/calculating-indices). Finally, the aggregate

indicator for the whole area of the social sector was obtained by adding together the individual partial indicators in accordance with the existing literature [6]. We give equal weight to each sector indicator in compiling the aggregate performance indicator; the assumption is strong, but stronger alternatives are lacking. It facilitates the comparison with the existing literature, where either the same assumption is made [2] or some sectors are not considered at all (thus being assigned a zero weight). For country $i$ at time $t$ we thus have:

$$
S P P I_{i, t}=\sum_{j=1}^{8} P_{i, j, t}
$$

The final values are characterized by a high degree of heterogeneity within the group of countries considered, ranging from 1.96 (Greece) to 6.34 (Norway). Higher indicators (greater than the median value 4.43) are associated with the Nordic countries (Norway, Denmark, the Netherlands, Finland and Sweden) and Luxembourg, Austria, France, Germany, Belgium and Slovenia (Table 1).

The disaggregated analysis of the index shows diversity in its composition. Performance levels of the "family", "health", "unemployment", "income inequality" and "poverty" sectors are higher in the Nordic systems (Norway, Denmark, Sweden, the Netherlands) and in some continental countries, notably Luxembourg. 
Table 1. The social protection performance index (2013).

\begin{tabular}{|c|c|c|c|c|c|c|c|c|c|}
\hline & Family & Health & $\begin{array}{l}\text { Labour } \\
\text { market }\end{array}$ & Old Age & Unemployment & Disability & $\begin{array}{c}\text { Income } \\
\text { inequality } \\
\text { (Gini index) }\end{array}$ & Poverty & $\begin{array}{c}\text { Final Index } \\
2013\end{array}$ \\
\hline \multicolumn{10}{|l|}{ Country } \\
\hline Austria & 0.71546 & 0.73333 & 0.57357 & 0.78301 & 0.95459 & 0.27485 & 0.69231 & 0.71852 & 5.44563 \\
\hline Belgium & 0.62240 & 0.66667 & 0.77395 & 0.31540 & 0.75814 & 0.29220 & 0.79487 & 0.44444 & 4.66809 \\
\hline Czech Republic & 0.16766 & 0.34667 & 0.67284 & 0.44560 & 0.81737 & 0.02246 & 0.84615 & 0.90370 & 4.22247 \\
\hline Denmark & 0.75796 & 0.62667 & 0.76844 & 0.75061 & 0.88648 & 0.67877 & 0.91453 & 0.88148 & 6.26494 \\
\hline Estonia & 0.21755 & 0.21333 & 0.48165 & 0.35513 & 0.80454 & 0.05139 & 0.00000 & 0.00000 & 2.12361 \\
\hline Finland & 0.62046 & 0.72000 & 0.58828 & 0.35330 & 0.80750 & 0.46712 & 0.84615 & 0.71852 & 5.12133 \\
\hline France & 0.57597 & 0.88000 & 0.66917 & 0.41993 & 0.72162 & 0.21753 & 0.57265 & 0.71111 & 4.76798 \\
\hline Germany & 0.60792 & 0.69333 & 0.69123 & 0.17665 & 0.97927 & 0.30079 & 0.58974 & 0.63704 & 4.67597 \\
\hline Greece & 0.18520 & 0.76000 & 0.06802 & 0.54095 & 0.00000 & 0.01775 & 0.15385 & 0.23704 & 1.96281 \\
\hline Hungary & 0.01661 & 0.00000 & 0.53313 & 0.89364 & 0.69398 & 0.00000 & 0.61538 & 0.51111 & 3.26386 \\
\hline Ireland & 0.34385 & 0.72000 & 0.44121 & 0.09413 & 0.65647 & 0.06867 & 0.44444 & 0.59259 & 3.36137 \\
\hline Italy & 0.23254 & 0.94667 & 0.69307 & 0.66748 & 0.51234 & 0.09884 & 0.30769 & 0.31111 & 3.76974 \\
\hline Luxembourg & 0.82886 & 0.82667 & 1.00000 & 0.51223 & 0.87858 & 0.79827 & 0.68376 & 0.60741 & 6.13577 \\
\hline Netherlands & 0.79851 & 0.76000 & 0.75925 & 1.00000 & 0.91412 & 0.32221 & 0.69231 & 0.69630 & 5.94269 \\
\hline Norway & 0.73652 & 0.81333 & 0.70593 & 0.40159 & 1.00000 & 1.00000 & 0.93162 & 0.75556 & 6.34456 \\
\hline Poland & 0.22776 & 0.18667 & 0.29230 & 0.24694 & 0.67522 & 0.01699 & 0.52137 & 0.48889 & 2.65613 \\
\hline Portugal & 0.44781 & 0.68000 & 0.88242 & 0.45477 & 0.45508 & 0.07558 & 0.16239 & 0.30370 & 3.46175 \\
\hline Slovak Republic & 0.04866 & 0.10667 & 0.64343 & 0.72555 & 0.53998 & 0.04050 & 0.78632 & 0.76296 & 3.65407 \\
\hline Slovenia & 0.55499 & 0.62667 & 0.86220 & 0.29279 & 0.73445 & 0.02904 & 0.90598 & 0.62222 & 4.62833 \\
\hline Spain & 0.30206 & 1.00000 & 0.69307 & 0.61064 & 0.08687 & 0.09320 & 0.12821 & 0.08889 & 3.00292 \\
\hline Sweden & 0.78848 & 0.84000 & 0.44305 & 0.35147 & 0.76703 & 0.55008 & 0.68376 & 0.54815 & 4.97201 \\
\hline United Kingdom & 0.56318 & 0.72000 & 0.00000 & 0.00000 & 0.80849 & 0.10657 & 0.02564 & 0.49630 & 2.72018 \\
\hline
\end{tabular}

Source: Our elaborations on OECD and Eurostat Data.

In the Mediterranean countries, in contrast, the better-performing components are represented by "health" and "the elderly", while markedly poor performances are highlighted by context indicators relating to the fight against poverty and to policies reducing income inequality. Anglo-Saxon countries perform well in the unemployment and poverty sector.

\subsection{Performance, Median Income and Distribution}

Equations (8) and (8') imply that $\beta g$ is directly related to $k_{m} Y_{m}$. Given that $k_{m}=\frac{Y_{m}+\overline{Y_{\min }}}{2 Y_{m}}, k_{m}$ increases with $\frac{\overline{Y_{\min }}}{Y_{m}}$. This ratio corresponds to the inverse of the percentile ratio $\mathrm{P} 50 / \mathrm{P} 10$, among the common measures of inequality, basically representing a distributional parameter (see claim 1 ). 
Figure 1 shows the relationship between our SPPI for the year 2013 and the average value of the product between the percentile ratio and the median income for the period 2009-2013 for the countries under consideration. We take the average value of $\mathrm{Y}_{\mathrm{m}}(\mathrm{P} 10 / \mathrm{P} 50)$ for the period 2009-2013 to consider the lag between the outcome of social policies in a given year and the expenditure decisions of previous years.

What emerges is a positive relationship, which hints at an explanation of differences in national choices about the level of protection based on differences in the level and the position in the distribution of the median voter's income. This can be connected both to the redistribution and the insurance motives outlined in the previous section. Since the main objective of the paper is to analyse efficiency in social expenditure, we do not elaborate further on this finding, turning, instead, to the analysis of social expenditure efficiency.

\section{The Inefficiency Parameter}

Our next step is to calculate the inefficiency parameter represented by $\alpha$ in the theoretical framework. Since the per capita social expenditure is $\alpha \beta g$, the value of $\alpha$ is simply given by $\alpha \beta g$ divided by $\beta g$, estimated in the previous section. From a conceptual point of view, we are calculating the ratio between the input of social policy (expenditure) and the output (the SPPI).

As an estimate for $\alpha \beta g$, we take per capita net public social expenditure, as a share of GDP. In particular, we assume a lagged effect from expenditure onto performance: we thus take the average value of per capita net social expenditure over the period 2009-2013 (at constant prices). The method is similar to the one applied in [2], therefore most of the same caveats apply. Thus, we are aware that

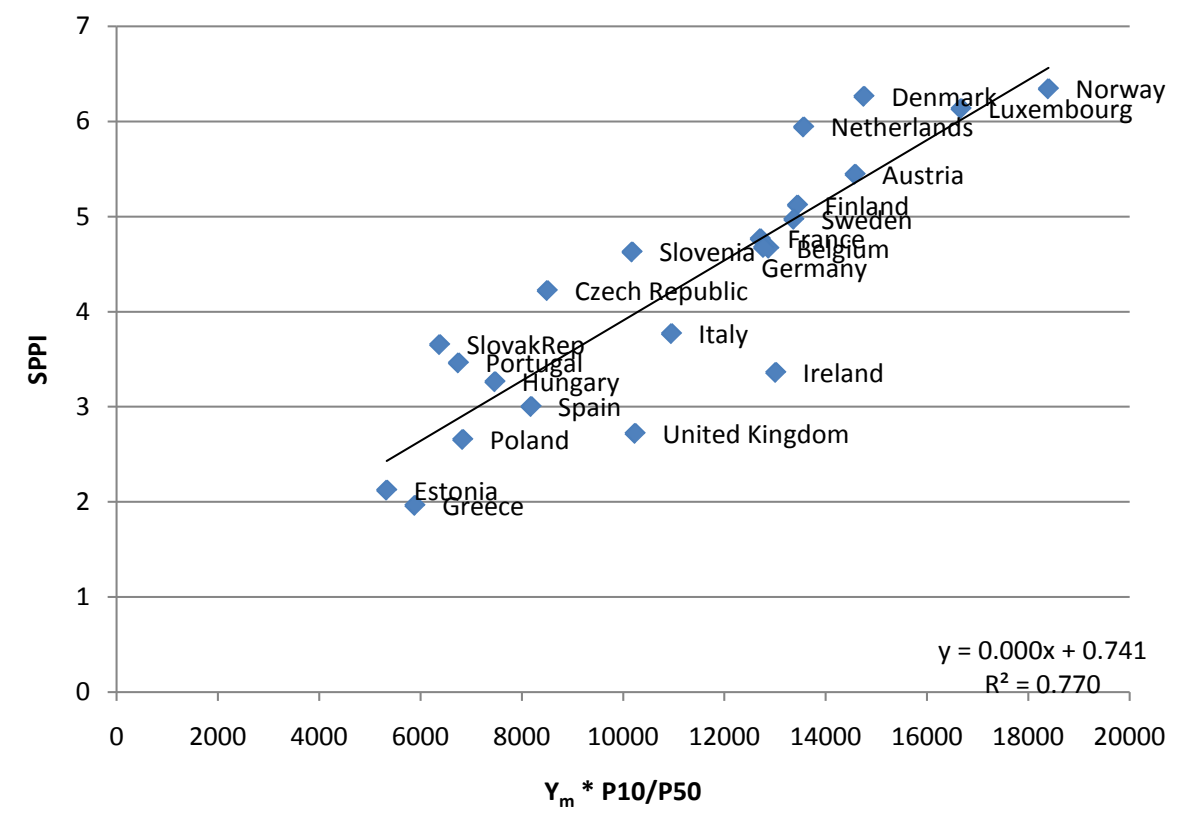

Figure 1. The social protection performance index and income distribution. Source: Our elaborations on OECD data (SOCX Database). Median income in PPP (US dollars). 
public expenditure data are not always fully comparable among countries and that its impact on performance cannot be always separated by that of other factors. Note that the existing literature uses gross social expenditure; instead, by using net social expenditure, we can correct for differences across countries stemming from different taxation levels on social benefits.

We can now obtain an estimate of $\alpha$ computing an indicator for social expenditure inefficiency for each country, $S E I_{i^{*}}$ To do this, we weigh the logarithm of average per capita net social expenditure, $N P S E_{p}$ by $S P P I_{i}$ (of course, the values of the indexes only give an ordering of countries):

The final values (Table 2) are characterized by a high degree of heterogeneity within the group of countries considered, ranging from 1.47 (Denmark) to 3.83 (Estonia). Based on this ranking, one can distinguish three groups of countries: the Nordic countries, with Luxembourg and Austria, with the lowest inefficiency indexes (between 1.7 and 1.83); the Continental countries, with inefficiency parameters between 1.84 and 2.28; the Mediterranean and Anglo-Saxon countries, with Poland, Hungary and Estonia, with fairly high inefficiency parameters (2.39 $-3.83)$

Table 2. The social expenditure inefficiency index (2013).

\begin{tabular}{cc}
\hline Country & SEII \\
\hline Austria & 1.688766 \\
Belgium & 1.978171 \\
Czech Republic & 2.032466 \\
Denmark & 1.467653 \\
Estonia & 3.838971 \\
Finland & 1.769576 \\
France & 1.943538 \\
Germany & 1.962848 \\
Greece & 3.330452 \\
Hungary & 2.578343 \\
Ireland & 2.705011 \\
Italy & 2.390322 \\
Luxembourg & 1.581171 \\
Netherlands & 1.53085 \\
Norway & 1.467002 \\
Poland & 3.093786 \\
Portugal & 2.511969 \\
Slovak Republic & 2.283473 \\
Slovenia & 1.869697 \\
Spain & 2.982955 \\
Sweden & 1.839119 \\
United Kingdom & 3.300212 \\
\hline
\end{tabular}


Unlike the result for general public expenditure in [2], inefficiency in social expenditure is not positively related to the amount of spending, as shown in Figure 2 (the same applies to the relationship between the SEII and the ratio of net social expenditure to GDP).

Differently from [11] [12] and [13], Ireland and the United Kingdom are at the same levels of inefficiency as the Mediterranean countries. As for the new Continental countries, differently from [13], the Czech Republic and Slovenia do not outperform the Northern countries, ranking with the other Continental countries and the Slovak Republic (even if Slovenia is quite near to Sweden), while Hungary joins Poland at the levels of the Mediterranean countries. This difference, besides the different time period under consideration, stems from the different measure of performance that we adopt, based on the outcomes of a set of social policy areas that is wider than those adopted in the above-mentioned literature. For instance, the lag of the Mediterranean countries w.r.t. the Anglo-Saxon ones in the area "unemployment" is compensated by a better performance in the fields of "health" (and "the elderly", as for the United Kingdom). Consequently, we believe that a general performance index can better assess the overall effect of social protection on social welfare.

As argued in Section 2, a higher level of the inefficiency parameter $\alpha$ should be inversely related to $\beta g$. This corresponds to an inverse relationship between the SPPI and the SEII. In the perspective of a cross-country comparison, we find that countries with an above average (2.14) inefficiency level have a below average (4.22) level of performance (Figure 3 ).

\section{Conclusions}

Our theoretical analysis of the relationship between social performance and efficiency predicts that the size of social protection increases with the median

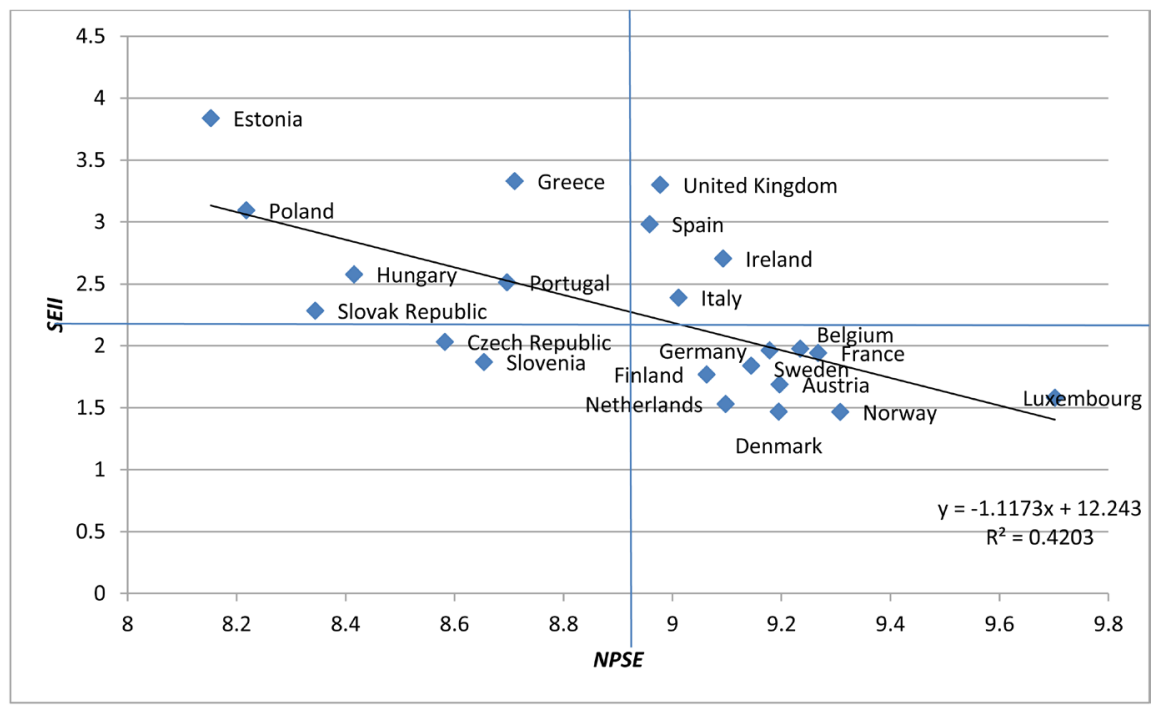

Figure 2. The social expenditure inefficiency index and net public social expenditure (2013). Source: Our elaborations on OECD Data. 


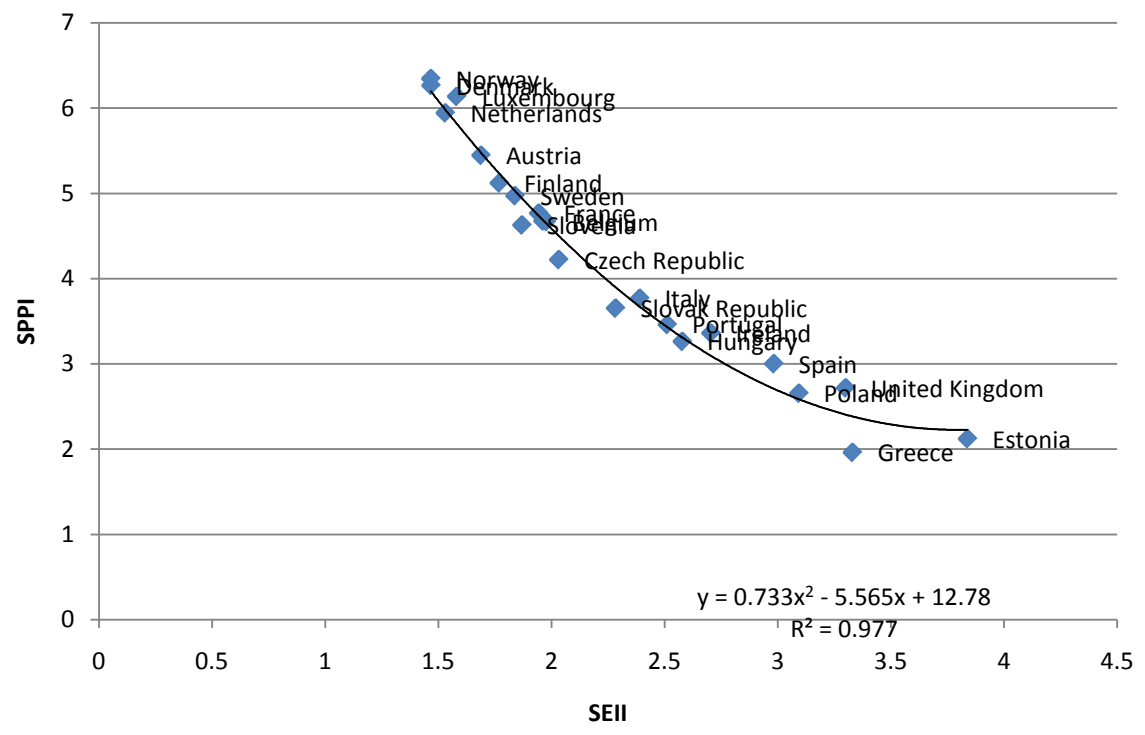

Figure 3. The relationship between the social protection performance index and the Social Expenditure Inefficiency Index Source: Our elaborations on OECD Data.

voter's income level and its proximity to the bottom end of the distribution and decreases as the inefficiency of social expenditures increases. These claims are supported by the data.

To test the model, we first constructed performance indexes for 22 European countries in 2013. While the literature on the effectiveness and the efficiency of welfare systems proposes sectorial analyses, we construct a composite performance index (SPPI) based on the outcomes of all main sectors of social policy. Then, we calculated an inefficiency index (SEII) as the ratio of net social expenditure to the performance index (existing studies use gross social expenditure).

We obtain a ranking of countries not completely in line with those found in the literature: for instance, Mediterranean and Anglo-Saxon countries end up being quite similar. We also find that, in the field of social protection, efficiency does not appear to be inversely related to the size of public intervention. The type of welfare system appears to be a more relevant factor in determining the effectiveness and efficiency of social expenditure. Of course, given the difficulties in cross-country data comparability and in separating the effect of public expenditure from that of other factors (just take life expectancy as an example), all the results are indicative. Also, the 22 countries have different levels of private social expenditure; these are limited in general, albeit higher in the Nordic countries. These findings can be of relevance within the debate on the link between the characteristics of welfare systems and their efficacy and effectiveness, to which we have already referred in the paper: by comparing the performance and efficiency rankings, we found that countries with higher expenditure efficiency present a greater homogeneity of performance in all subsectors considered. 
This might be related to the cross effects of sectorial policies, that thus tend to reinforce each other. For instance, a higher expenditure level in support of families, like childcare, encourages female participation in the labour market and can therefore contribute to reduce poverty and income inequality. As a policy implication, the paper suggests that expenditure policy should follow a multitarget approach, not devoting resources only to contrast some particular social risks, given that some sectorial policies can have indirect positive effects on other areas, thus guaranteeing a more efficient use of resources.

\section{References}

[1] Mandl, U., Dierx, A. and Ilzkovitz, F. (2008) The Effectiveness and Efficiency of Public Spending. Economics Papers, 301, European Commission.

[2] Afonso, A., Schuknecht, L. and Tanzi, V. (2005) Public Sector Efficiency: An International Comparison. Public Choice, 123, 321-347.

https://doi.org/10.1007/s11127-005-7165-2

[3] Afonso, A. and Kazemi, M. (2017) Assessing Public Spending Efficiency in 20 OECD Countries. In: Boekemeier, B. and Greiner, A., Eds., Inequality and Finance in Macrodynamics, Springer International Publishing, 7-42. https://doi.org/10.1007/978-3-319-54690-2__2

[4] Afonso, A., Schuknecht, L. and Tanzi, V. (2010) Public Sector Efficiency: Evidence from New EU Member States and Emerging Markets. Applied Economics, 42, 2147-2164. https://doi.org/10.1080/00036840701765460

[5] Tanzi, V. (1998) Government Role and the Efficiency of Policy Instruments. In: Sorenson, P., Ed., Public Finance in a Changing World, MacMillan Press, 51-79. https://doi.org/10.1007/978-1-349-14336-8_3

[6] Tanzi, V. and Schuknecht, L. (2000) Public Spending in the 20th Century: A Global Perspective. Cambridge University Press, Cambridge. https://doi.org/10.1017/CBO9780511625800

[7] Clements, B. (2002) How Efficient Is Education Spending in Europe? European Review of Economics and Finance, 1, 3-26.

[8] Vanden Eeckhaut, P., Tulkens, H. and Jamar, M.A. (1993) Cost-Efficiency in Belgian Municipalities. In: Fried, H., Lovell, C. and Schmidt, S., Eds., The Measurement of Productive Efficiency. Techniques and Applications, Oxford University Press, New York.

[9] Fakin, B. and de Crombrugghe, A. (1997) Fiscal Adjustment in Transition Economies: Social Transfers and the Efficiency of Public Spending: A Comparison with OECD Countries. Policy Research Working Paper 1083, World Bank, Washington DC.

[10] Gupta, S. and Verhoeven, M. (2001) The Efficiency of Government Expenditure. Experiences from Africa. Journal of Policy Modelling, 23, 433-467.

[11] Boeri, T. (2002) Let Social Policy Models Compete and Europe Will Win. Paper Presented at a Conference Hosted by the Kennedy School of Government, Harvard University, 11-12 April.

[12] Sapir, A. (2005) Globalisation and the Reform of European Social Models. Bruegel Policy Brief, 1, 1-8.

[13] Caruana, C. (2010) Measuring the Efficiency and Effectiveness of the Welfare State: A Comparative Study of the EU-27 Member States. Bank of Valletta Review, 42, 
75-106.

[14] Sinn, H.W. (1995) A Theory of the Welfare State. Scandinavian Journal of Economics, 97, 495-526. https://doi.org/10.2307/3440540

[15] Buchanan, J.M. and Tullock, G. (1965) The Calculus of Consent. University of Michigan Press, Ann Arbor.

[16] Mishan, E.J. (1972) The Futility of Pareto Efficient Distributions. American Economic Review, 62, 971-976.

[17] Brennan, G. (1973) Pareto Desirable Redistribution: The Non-Altruistic Dimension. Public Choice, 14, 43-67. https://doi.org/10.1007/BF01718441

[18] Migué, J.L. and Bélanger, G. (1974) Towards a General Theory of Managerial Discretion. Public Choice, 17, 27-51. https://doi.org/10.1007/BF01718995

[19] Downs, A. (1957) An Economic Theory of Democracy. Harper and Row, New York.

[20] Meltzer, A.H. and Richard, S.F. (1981) A Rational Theory of the Size of Government. Journal of Political Economy, 89, 914-925. https://doi.org/10.1086/261013

[21] Persson, T. and Tabellini, G. (1994) Is Inequality Harmful for Growth? American Economic Review, 84, 600-621.

[22] Alesina, A. and Rodrik, D. (1994) Distributive Politics and Economic Growth. Quarterly Journal of Economics, 109, 465-490. https://doi.org/10.2307/2118470

[23] Milanovic, B. (2000) The Median-Voter Hypothesis, Income Inequality, and Income Redistribution: An Empirical Test with the Required Data. European Journal of Social Policy, 16, 367-410.

[24] Barnes, L. (2013) Does Median Voter Income Matters? The Effect of Inequality and Turnout on Government Spending. Political Studies, 61, 82-100. https://doi.org/10.1111/j.1467-9248.2012.00952.x

[25] Wagstaff, A. (2000) Research on Equity, Poverty and Health: Lessons for the Developing World. World Bank, Human Development Network, Washington DC.

[26] Marduch, J. (1995) Income Smoothing and Consumption Smoothing. Journal of Economic Perspectives, 9, 103-114. https://doi.org/10.1257/jep.9.3.103

[27] Brueckner, J.K. (2000) Welfare Reform and the Race to the Bottom: Theory and Evidence. Southern Economic Journal, 66, 505-625. https://doi.org/10.2307/1061423

[28] Razin, A. and Sadka, E. (2005) The Decline of the Welfare State. Demography and Globalization. CESIfo Book Series, The MIT Press.

[29] Saunders, P. (1991) Selectivity and Targeting in Income Support: The Australian Experience. Journal of Social Policy, 20, 299-326. https://doi.org/10.1017/S0047279400018900

[30] Swann, C. (2010) WIC Eligibility and Participation: The Roles of Changing Policies, Economic Conditions, and Demographics. The B.E. Journal of Economic Analysis \& Policy, 10. https://doi.org/10.2202/1935-1682.2352

[31] Adema, W., From, P. and Ladaique, M. (2014) How Much Do OECD Countries Spend on Social Protection and How Redistributive Are Their Tax/benefit Systems. International Social Security Review, 67, 1-25. https://doi.org/10.1111/issr.12028

[32] Gouyette, C. and Pestieau, P. (1999) Efficiency of the Welfare State. Kyklos, 52, 537-553. https://doi.org/10.1111/j.1467-6435.1999.tb00232.x

[33] Antonelli, M.A. and De Bonis, V. (2017) How Do European Welfare States Perform? Social Europe, July. 


\section{Appendix}

\section{Methodological notes and data for outcomes indicators}

This appendix provides some methodological notes on some outcomes' indicators used to calculate the performance index. In the paper, we consider $7 \mathrm{sec}-$ tors of social expenditure (family, health, labour market, elderly, disabled, unemployment, inequality) and 8 sector indicators (we add poverty) for their related outcomes (Figure A1).

In some cases, the outcomes' indicators are data (maternal employment, life expectancy, unemployment rate, Gini index, poverty index) directly available on OECD databases. In other cases, some elaboration was needed. For example, for family and disabled, we use monetary amounts considered net of fiscal measures and expressed in PPP (US dollar) to make the international comparison possible. While for the disabled, we directly use the available Eurostat data on the monetary benefits that, on average, national governments allocate in the form of disability pensions or monetary transfers, for the family available income we simulated the net disposable income of a "typical" family-which we adopt as a benchmark-consisting of two children and two working parents with, respectively, a gross income from employment equal to 100 percent and 67 percent of

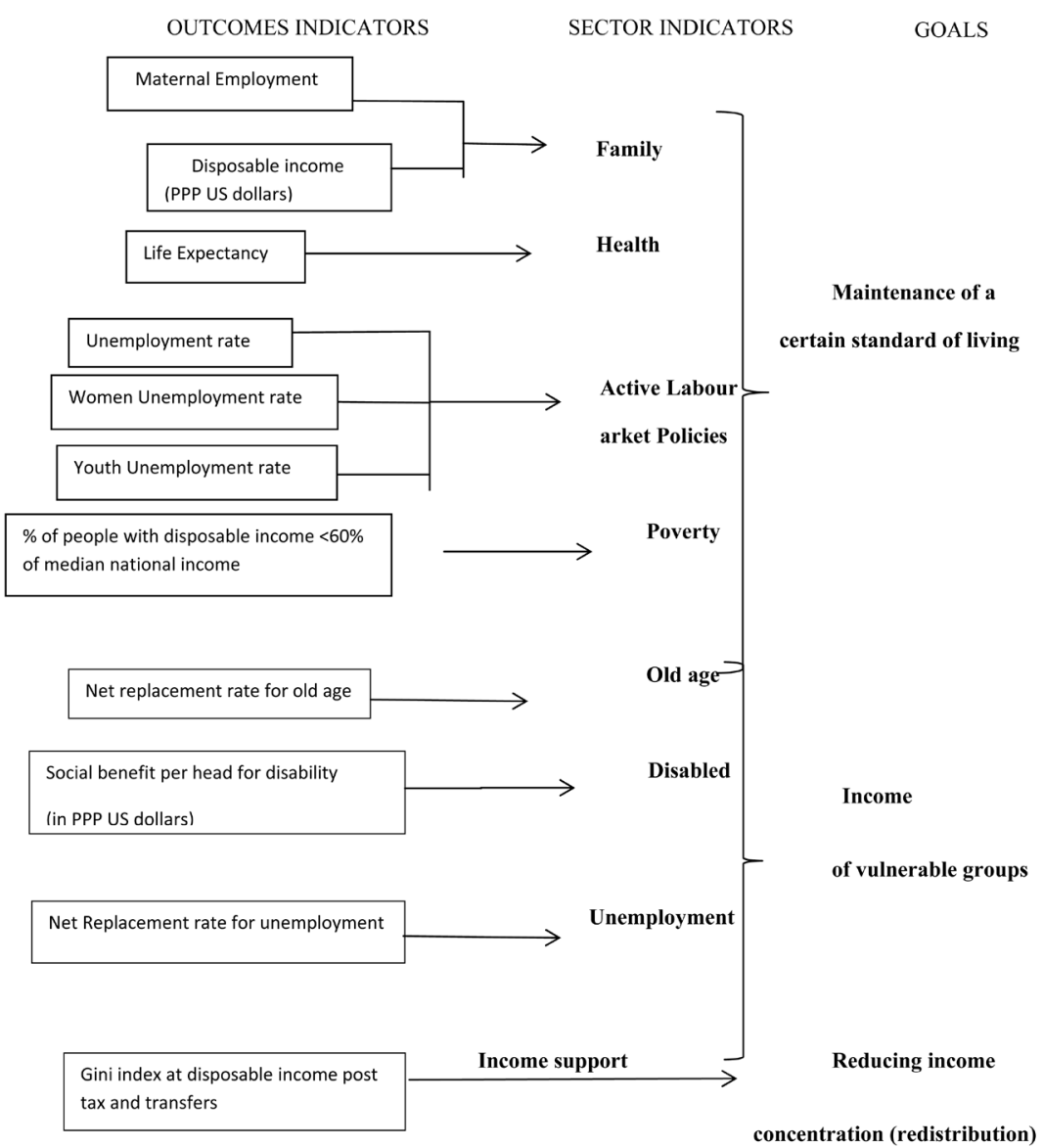

Figure A1, Outcomes indicators for social policies. 
the average income from employment in their country of residence. Net disposable income is calculated by subtracting the income tax (considering deductions or tax credits) and social contributions from gross taxable income (adjusted for deductions) and adding monetary benefits. For the simulation analysis, the OECD's tax-benefit calculator model (available at the following link: http://www.oecd.org/els/soc/benefitsandwagestax-benefitcalculator.htm) was used. The results of the simulation are in Table A1.

Other income support policies target groups of individuals who exhibit a certain degree of vulnerability, due to life cycle and market risks, within the framework of the market economy: the elderly, the unemployed. For each of these categories, the benchmark indicator that we have identified is the average amount of available resources which the various national welfare systems guarantee to them. In all cases, we consider monetary benefits in net terms, i.e. net of

Table A1. Net family income (2013).

\begin{tabular}{|c|c|}
\hline Countries & Net Family income in PPP (US dollars) 2013 \\
\hline Austria & 64998.75 \\
\hline Belgium & 62648.28 \\
\hline Czech Republic & 32836.91 \\
\hline Denmark & 58836.54 \\
\hline Estonia & 30900.19 \\
\hline Finland & 59222.34 \\
\hline France & 57993.89 \\
\hline Germany & 66490.35 \\
\hline Greece & 49334.96 \\
\hline Hungary & 29814.12 \\
\hline Ireland & 60947.56 \\
\hline Italy & 50506.70 \\
\hline Luxembourg & 84729.00 \\
\hline Netherlands & 71318.07 \\
\hline Norway & 72517.29 \\
\hline Poland & 29406.64 \\
\hline Portugal & 39433.96 \\
\hline Slovak Republic & 28512.05 \\
\hline Slovenia & 37712.85 \\
\hline Spain & 52286.35 \\
\hline Sweden & 60947.32 \\
\hline United Kingdom & 68063.40 \\
\hline
\end{tabular}

Source: elaboration on OECD tax-benefit calculator data. 
fiscal measures (direct taxation, resulting from social transfers, indirect taxation of consumption by recipients of transfers and tax benefits for social welfare purposes). For the elderly, we have used the net replacement rate relating to compulsory pension schemes, which represents the percentage of individual income, net of contributions and taxes, that the pension system guarantees after exiting the job market. Formally, this is the ratio of the net pension to the labour income net of tax. Three levels of labour income were considered: 50 percent, 100 percent and 150 percent of national average labour income (AW) (Table A2).

From a methodological point of view, we repeat a simulation analysis to calculate the net replacement rate of unemployment benefits during the first year of unemployment, which represents the proportion of net labour income replaced by net benefits received in the event of unemployment.

Table A2. Net replacement rate for pensions (2013).

\begin{tabular}{|c|c|c|c|}
\hline & \multicolumn{3}{|c|}{ Net Replacement Rate for pensions (2013) } \\
\hline & Low earner $(0.5 \mathrm{AW})$ & Average earner (AW) & High earner $(1.5 \mathrm{AW})$ \\
\hline Austria & 91.2 & 90.2 & 86.2 \\
\hline Belgium & 80.7 & 62.1 & 48.3 \\
\hline Czech Republic & 97.8 & 63.8 & 50.8 \\
\hline Denmark & 117.5 & 77.4 & 67.4 \\
\hline Estonia & 79.7 & 62.4 & 55.5 \\
\hline Finland & 71.3 & 62.8 & 63.2 \\
\hline France & 75.9 & 71.4 & 60.9 \\
\hline Germany & 55.2 & 57.1 & 56.1 \\
\hline Greece & 92.5 & 70.5 & 65 \\
\hline Hungary & 94.4 & 95.2 & 96.1 \\
\hline Ireland & 75.5 & 44.8 & 34.6 \\
\hline Italy & 83.9 & 81.5 & 83.3 \\
\hline Luxembourg & 87.1 & 69.4 & 66.8 \\
\hline Netherlands & 104.8 & 101.1 & 97.2 \\
\hline Norway & 91.1 & 62.8 & 51.3 \\
\hline Poland & 61.3 & 59.5 & 59.1 \\
\hline Portugal & 77.7 & 67.8 & 68.4 \\
\hline Slovak Republic & 88.1 & 85.4 & 84.7 \\
\hline Slovenia & 63.5 & 63.3 & 60.6 \\
\hline Spain & 79.5 & 80.1 & 79.8 \\
\hline Sweden & 68.8 & 55.3 & 72.9 \\
\hline United Kingdom & 67.2 & 41.8 & 30.5 \\
\hline
\end{tabular}

Source: Pensions at a Glance, OECD Pensions Statistics (database). 
The latter, in turn, depend on both labour income and the recipient's family situation. Therefore, two income categories were considered (67 percent and 100 percent of national average labour income) and, within each of them, six types of family: three typical families (single parent, single-earner households and families with both partners in employment) without children and three families of the same types with two underage children (Table A3 and Table A4). In both

Table A3. Net replacement rates unemployed: case 1 (67\% AW) (2013).

\begin{tabular}{|c|c|c|c|c|c|c|}
\hline \multirow[b]{3}{*}{ Countries } & \multicolumn{6}{|c|}{$67 \%$ of Average Wage (AW) } \\
\hline & \multicolumn{3}{|c|}{ No children } & \multicolumn{3}{|c|}{2 children } \\
\hline & Single person & $\begin{array}{c}\text { One-earner } \\
\text { married } \\
\text { couple }\end{array}$ & $\begin{array}{c}\text { Two-earner } \\
\text { married } \\
\text { couple }\end{array}$ & $\begin{array}{c}\text { Lone } \\
\text { parents }\end{array}$ & $\begin{array}{c}\text { One-earner } \\
\text { married } \\
\text { couple }\end{array}$ & $\begin{array}{c}\text { Two-earner } \\
\text { married } \\
\text { couple }\end{array}$ \\
\hline Austria & 55 & 57 & 80 & 71 & 72 & 85 \\
\hline Belgium & 90 & 83 & 84 & 95 & 82 & 85 \\
\hline $\begin{array}{c}\text { Czech Re- } \\
\text { public }\end{array}$ & 65 & 65 & 87 & 67 & 67 & 88 \\
\hline Denmark & 84 & 85 & 92 & 89 & 87 & 92 \\
\hline Estonia & 55 & 57 & 77 & 65 & 62 & 79 \\
\hline Finland & 59 & 59 & 80 & 74 & 69 & 84 \\
\hline France & 69 & 65 & 84 & 71 & 68 & 84 \\
\hline Germany & 59 & 59 & 86 & 81 & 83 & 90 \\
\hline Greece & 39 & 40 & 68 & 46 & 46 & 70 \\
\hline Hungary & 68 & 68 & 84 & 76 & 76 & 87 \\
\hline Ireland & 50 & 80 & 75 & 50 & 75 & 81 \\
\hline Italy & 72 & 76 & 86 & 81 & 78 & 88 \\
\hline Luxembourg & 83 & 81 & 90 & 90 & 89 & 93 \\
\hline Netherlands & 76 & 77 & 84 & 67 & 81 & 77 \\
\hline Norway & 68 & 69 & 84 & 79 & 73 & 86 \\
\hline Poland & 49 & 50 & 75 & 80 & 56 & 76 \\
\hline Portugal & 75 & 75 & 93 & 79 & 78 & 94 \\
\hline $\begin{array}{c}\text { Slovak Re- } \\
\text { public }\end{array}$ & 62 & 58 & 85 & 72 & 57 & 86 \\
\hline Slovenia & 86 & 83 & 93 & 85 & 88 & 96 \\
\hline Spain & 78 & 75 & 89 & 76 & 74 & 88 \\
\hline Sweden & 63 & 63 & 81 & 71 & 67 & 83 \\
\hline $\begin{array}{c}\text { United } \\
\text { Kingdom }\end{array}$ & 20 & 31 & 60 & 47 & 56 & 67 \\
\hline
\end{tabular}

Source: OECD Benefits and wages statistics http://www.oecd.org/els/benefits-and-wages-statistics.htm 
Table A4. Net replacement rates unemployed: case 1 (67\% AW) (2013).

\begin{tabular}{|c|c|c|c|c|c|c|}
\hline \multirow[b]{3}{*}{ Countries } & \multicolumn{6}{|c|}{$100 \%$ of Average Wage (AW) } \\
\hline & \multicolumn{3}{|c|}{ No children } & \multicolumn{3}{|c|}{2 children } \\
\hline & $\begin{array}{l}\text { Single } \\
\text { person }\end{array}$ & $\begin{array}{l}\text { One-earner } \\
\text { married couple }\end{array}$ & $\begin{array}{c}\text { Two-earner } \\
\text { married } \\
\text { couple }\end{array}$ & $\begin{array}{l}\text { Lone } \\
\text { parents }\end{array}$ & $\begin{array}{c}\text { One-earner } \\
\text { married } \\
\text { couple }\end{array}$ & $\begin{array}{c}\text { Two-earner } \\
\text { married } \\
\text { couple }\end{array}$ \\
\hline Austria & 55 & 56 & 76 & 67 & 68 & 81 \\
\hline Belgium & 67 & 63 & 71 & 74 & 64 & 74 \\
\hline Czech Republic & 65 & 65 & 83 & 70 & 66 & 89 \\
\hline Denmark & 58 & 60 & 75 & 67 & 64 & 76 \\
\hline Estonia & 54 & 56 & 73 & 60 & 61 & 74 \\
\hline Finland & 58 & 58 & 76 & 70 & 65 & 79 \\
\hline France & 67 & 67 & 80 & 71 & 68 & 81 \\
\hline Germany & 59 & 59 & 83 & 71 & 69 & 88 \\
\hline Greece & 28 & 28 & 57 & 33 & 34 & 59 \\
\hline Hungary & 45 & 45 & 67 & 57 & 56 & 72 \\
\hline Ireland & 36 & 57 & 63 & 48 & 67 & 69 \\
\hline Italy & 57 & 60 & 75 & 69 & 69 & 77 \\
\hline Luxembourg & 85 & 82 & 88 & 93 & 89 & 92 \\
\hline Netherlands & 75 & 77 & 83 & 68 & 81 & 78 \\
\hline Norway & 65 & 66 & 79 & 76 & 69 & 81 \\
\hline Poland & 33 & 35 & 60 & 53 & 41 & 62 \\
\hline Portugal & 75 & 75 & 95 & 77 & 77 & 98 \\
\hline Slovak Republic & 65 & 59 & 82 & 93 & 58 & 84 \\
\hline Slovenia & 68 & 67 & 81 & 77 & 72 & 84 \\
\hline Spain & 56 & 56 & 74 & 70 & 70 & 82 \\
\hline Sweden & 44 & 44 & 67 & 53 & 48 & 68 \\
\hline $\begin{array}{c}\text { United } \\
\text { Kingdom }\end{array}$ & 14 & 22 & 50 & 40 & 48 & 56 \\
\hline
\end{tabular}

Source: OECD Benefits and wages statistics http://www.oecd.org/els/benefits-and-wages-statistics.htm

cases, we consider families which do not qualify for cash housing assistance or social assistance while working. 


\section{Databases}

Eurostat, Social Protection Benefits Data available at

http://ec.europa.eu/eurostat/tgm/table.do?tab=table\&init=1\&plugin=1\&languag $\underline{\mathrm{e}=\mathrm{en} \& \mathrm{pcode}=\mathrm{tps} 00107}$

OECD, Social Expenditure Database (SOCX) available at

http://www.oecd.org/social/expenditure.htm

OECD, Family Database available at

http://www.oecd.org/els/family/database.htm

OECD, Tax-benefit calculator available at

http://www.oecd.org/social/soc/benefitsandwagestax-benefitcalculator.htm

OECD, Unemployment Data available at

https://data.oecd.org/unemp/harmonised-unemployment-rate-hur.htm

OECD, Pensions at Glance- Pensions Statistics available at

http://www.oecd-ilibrary.org/social-issues-migration-health/data/oecd-pensions -statistics/pensions-at-a-glance-2

OECD, Benefits and wages statistics available at http://www.oecd.org/els/benefits-and-wages-statistics.htm

OECD, Income Distribution and Poverty Database available at http://stats.oecd.org/Index.aspx?DataSetCode=IDD 